Received: 7 Februari 2021

Revised: 7 Juni 2021

Accepted: 23 Juni 2021

Published: 30 Juni 2021

\title{
Pengelompokkan Provinsi di Indonesia Berdasarkan Faktor Penyebab Balita Stunting Menggunakan Analisis Cluster Hierarki
}

\author{
Dodi Satriawan ${ }^{1, a)}$, Dwi Agus Styawan 2,b) \\ ${ }^{1}$ Badan Pusat Statistik Kab. Padang Lawas Utara, Jl. Lintas Gunung Tua-Padangsidimpuan KM4 \\ 2 Jl. Arungbinang No. 17A Kebumen \\ E-mail: ${ }^{\text {a) }}$ dodisatriawan@bps.go.id, ${ }^{\text {b) }}$ dwi.agus@bps.go.id
}

\begin{abstract}
The stunting condition is characterized by the growth of childrens who are slow and fail to reach normal height. Some of the causes of stunting include household access to sanitation and drinking water sources, initiation of early breastfeeding, exclusive breastfeeding, full immunization, household income, and household access to nutritious food. This study aims to classify provinces in Indonesia based on the causes of stunting. The source of the data used is secondary data from the Ministry of Health and BPS in 2017. Clustering was carried out using the ward method cluster analysis. The clustering results are four groups with different characteristics. The first group of 16 provinces was a group with a high stunting factor. The second group consisting of 8 provinces was a group with a moderate stunting factor. The third group consisting of 6 provinces is a group with a low stunting factor. The fourth group consisting of 4 provinces is a group with a very high stunting factor.
\end{abstract}

Keyword: Health, Stunting, Cluster Analysis, Ward Method.

\begin{abstract}
Abstrak
Kondisi stunting ditandai dengan pertumbuhan anak-anak yang lambat dan gagal mencapai tinggi badan normal. Beberapa faktor penyebab stunting antara lain akses rumah tangga terhadap sanitasi dan sumber air minum, inisiasi menyusui dini, pemberian ASI eksklusif, pemberian imunisasi lengkap, pendapatan rumah tangga, serta akses rumah tangga terhadap makanan bergizi. Penelitian ini bertujuan untuk mengelompokkan provinsi di Indonesia berdasarkan faktor penyebab stunting. Sumber data yang digunakan adalah data sekunder dari Kementerian Kesehatan dan BPS tahun 2017. Pengelompokkan dilakukan dengan menggunakan analisis cluster metode ward. Hasil pengelompokkan adalah empat kelompok dengan karakteristik yang berbeda-beda. Kelompok pertama beranggotakan 16 provinsi merupakan kelompok dengan faktor stunting tinggi. Kelompok kedua beranggotakan 8 provinsi merupakan kelompok dengan faktor stunting sedang. Kelompok ketiga beranggotakan 6 provinsi merupakan kelompok dengan faktor stunting rendah. Kelompok empat beranggotakan 4 provinsi merupakan kelompok dengan faktor stunting sangat tinggi.
\end{abstract}

Kata kunci: Kesehatan, Stunting, Analisis Cluster, Metode Ward. 


\section{PENDAHULUAN}

Salah satu tujuan yang diamanatkan dalam Sustainable Development Goals (SDGs) adalah mengakhiri kelaparan, mencapai ketahanan pangan dan peningkatan gizi, serta mencanangkan pertanian berkelanjutan. Indikator untuk mengukur peningkatan gizi diantaranya adalah menurunnya prevalensi balita stunting (tinggi badan kurang). Indikator ini mengukur persentase balita usia dua tahun atau lebih dengan tinggi badan di bawah ketinggian rata-rata penduduk acuan (BPS, 2014).

Pada dasarnya stunting merupakan kondisi gagal pertumbuhan pada anak akibat kekurangan gizi dalam waktu yang lama (WHO, 2014). Kekurangan gizi ini sebagai dampak dari pemberian makanan yang tidak sesuai dengan kebutuhan gizi. Hal ini terjadi sejak janin dalam kandungan sampai awal kehidupan anak. Karakteristik kekurangan gizi inilah yang mengakibatkan anak tumbuh lebih pendek dari anak normal seusianya (Kemenkes, 2016).

Stunting pada anak-anak berdampak serius pada perkembangan fisik, mental, dan emosional anakanak. Pada usia sekolah, anak yang stunting akan kehilangan tingkat kecerdasan sebesar $10-15$ poin (Bappenas, 2011). Bahkan dalam jangka panjang, stunting juga akan berdampak pada menurunnya produktifitas, menghambat pertumbuhan ekonomi, serta meningkatkan kemiskinan dan ketimpangan (TNP2K, 2017). Hal ini senada dengan pendapat dari United Nations International Children's Fund (Unicef) yang menyatakan bahwa stunting merupakan prediktor buruknya kualitas sumber daya manusia yang diterima secara luas, yang selanjutnya menurunkan kemampuan produktif suatu bangsa di masa yang akan datang (Unicef, 2012).

Berdasarkan hasil Pemantauan Status Gizi (PSG) yang dilakukan oleh Ditjen Kesehatan Masyarakat Kementerian Kesehatan (Kemenkes), prevalensi balita stunting di Indonesia cenderung meningkat (Kemenkes, 2018). Pada 2014, prevalensi balita stunting di Indonesia mencapai 28,9 persen (Kemenkes, 2016). Angka prevalensi ini kemudian meningkat menjadi 29 persen pada 2015. Pada 2016, prevalensi balita stunting di Indonesia sempat menurun menjadi 27,54 persen (Kemenkes, 2017). Namun, pada 2017 prevalensi balita stunting di Indonesia kembali meningkat menjadi 29,6 persen. Berdasarkan klasifikasi yang telah ditetapkan oleh World Health Organization (WHO), prevalensi balita stunting di Indonesia ini tergolong tinggi, sebab masih di atas 20 persen (Supariarsa, 2012).

Berbagai upaya terus dilakukan oleh pemerintah untuk menekan prevalensi balita stunting. Upayaupaya ini dinyatakan melalui Perpres Nomor 42 Tahun 2013, tentang Gerakan Nasional Percepatan Perbaikan Gizi. Perpres ini merupakan upaya bersama antara pemerintah dan masyarakat melalui penggalangan partisipasi dan kepedulian pemangku kepentingan secara terencana dan terkoordinasi untuk percepatan perbaikan gizi masyarakat dengan prioritas pada Seribu Hari Pertama Kehidupan (Notoatmodjo, 2013).

Namun, upaya-upaya yang telah dilakukan pemerintah belum terlalu efektif dalam menurunkan prevalensi balita stunting di Indonesia. Hal ini salah satunya disebabkan oleh penerapan kebijakan yang diterapkan secara merata di setiap wilayah, tanpa memperhatikan karakteristik faktor stunting di wilayah terkait (Utomo, 2018). Bagaimanapun juga, Indonesia merupakan negara besar yang terdiri dari beberapa wilayah dengan karakteristik-karakteristik yang berbeda. Karakteristik- karakteristik ini salah satunya adalah terkait dengan faktor penyebab stunting.

Kajian atau penelitian terkait faktor-faktor penyebab stunting di Indonesia telah relatif banyak dilakukan. Hasil penelitian menunjukkan bahwa pendapatan keluarga, pemberian ASI eksklusif, dan imunisasi lengkap berpengaruh terhadap kejadian stunting pada bayi (AL Rahmad, Hendra, \& Miko, 2016). Hasil penelitian ini senada dengan penelitian yang dilakukan di Kelurahan Beringin Jaya, Kecamatan Kemiling, Kota Bandar Lampung. Penelitian ini membuktikan bahwa asupan energi, asupan protein, pengetahuan ibu, dan pemberian ASI eksklusif berpengaruh terhadap kejadian balita stunting (Bertalina \& Amelia, 2018). Demikian juga dengan hasil penelitian lainnya yang menyatakan bahwa penundaan inisiasi menyusui dini dan pemberian ASI tidak eksklusif berpengaruh terhadap kejadian stunting pada anak usia 6 - 24 bulan (Permadi \& Rizal, 2016).

Faktor-faktor lain penyebab balita stunting, sebagaimana hasil kajian TNP2K, adalah praktek pengasuhan yang kurang baik, terbatasnya layanan kesehatan, masih kurangnya akses rumah tangga terhadap makanan bergizi, serta kurangnya akses rumah tangga terhadap sanitasi dan air bersih (TNP2K, 2018). Hasil kajian TNP2K ini sejalan dengan penelitian yang dilakukan Fakultas Kesehatan 
Masyarakat Universitas Airlangga terhadap 34 balita di Puskesmas Tanah Kali Kedinding, Surabaya. Hasil penelitian tersebut menunjukkan bahwa terdapat hubungan antara panjang badan lahir balita, riwayat ASI eksklusif, pendapatan keluarga, pendidikan ibu dan pengetahuan gizi ibu terhadap kejadian stunting pada balita (Ni'mah \& Nadhiroh, 2015). Demikian halnya dengan penelitian yang dilakukan oleh Fakultas Kedokteran dan Fakultas Kesehatan Masyarakat Universitas Diponegoro terhadap 77 anak stunting dan 77 anak tidak stunting di Puskesmas Brebes, Kabupaten Brebes. Hasil penelitian ini menyebutkan bahwa faktor risiko yang berpengaruh terhadap kejadian stunting pada anak umur $12-24$ bulan di Kecamatan Brebes adalah tingkat kecukupan energi yang rendah, protein yang rendah, seng yang rendah, berat badan lahir rendah, dan tingginya pajanan pestisida (Wellina, Kartasurya, \& Rahfilludin, 2016).

Berbagai kajian faktor penyebab stunting di atas lebih cenderung dilakukan melalui pendekatan makro maupun mikro individu/rumah tangga. Namun, bagaimana karakteristik faktor penyebab stunting tersebut di setiap provinsi di Indonesia relatif belum banyak dikaji. Padahal, masing-masing provinsi memiliki karakteristik faktor-faktor penyebab stunting yang berbeda. Hal ini tentu memerlukan penanganan dan kebijakan yang berbeda pula antar provinsi.

Pembentukan kelompok pada dasarnya dapat mempermudah untuk melihat karakteristik faktor penyebab balita stunting di Indonesia. Pembentukan kelompok ini didasarkan pada kesamaan karakteristik faktor penyebab balita stunting pada setiap provinsi di Indonesia. Berdasarkan penelitianpenelitian sebelumnya, maka karakteristik terkait sanitasi dan sumber air minum, inisiasi menyusui dini, pemberian ASI eksklusif, pemberian imunisasi lengkap, pendapatan rumah tangga, serta akses rumah tangga terhadap makanan bergizi dijadikan sebagai dasar pengelompokkan. Provinsi-provinsi yang cenderung memiliki kesamaan karakteristik akan berada pada satu kelompok yang sama. Pengelompokkan ini akan memudahkan pemerintah dalam melihat karakteristik faktor penyebab balita stunting di setiap wilayah. Oleh karena itu, penulis tertarik mengkaji bagaimana pengelompokan provinsi-provinsi di Indonesia berdasarkan faktor penyebab balita stunting dan bagaimana karakteristik kelompok-kelompok tersebut. Melalui pengelompokkan provinsi ini diharapkan berbagai program dan kebijakan penurunan prevalensi balita stunting lebih sesuai dengan karakteristik dan permasalahan masing-masing wilayah.

\section{METODOLOGI}

\section{Bahan dan Data}

Data yang digunakan dalam penelitian ini adalah data sekunder, yaitu Publikasi "Data dan Informasi Profil Kesehatan Indonesia 2017" dari Kementerian Kesehatan dan data Survei Sosial Ekonomi Nasional (Susenas) tahun 2017 yang dilakukan oleh BPS. Adapun variabel yang digunakan dalam penelitian ini adalah sebagai berikut:

$\mathrm{X} 1$ : Persentase rumah tangga yang memiliki sanitasi layak.

$\mathrm{X} 2$ : Persentase rumah tangga yang memiliki sumber air minum layak.

X3 : Persentase bayi yang mendapatkan ASI eksklusif selama 6 bulan.

$\mathrm{X} 4$ : Persentase bayi yang mendapatkan inisiasi menyusui dini.

X5 : Persentase anak usia $12-59$ bulan yang mendapatkan imunisasi lengkap.

X6 : Rata-rata pengeluaran rumah tangga perkapita perbulan.

X7 : Rata-rata konsumsi kalori perkapita perhari

Penelitian ini menggunakan metode analisis deskriptif untuk mengetahui gambaran prevalensi balita stunting setiap provinsi di Indonesia. Sedangkan pengelompokkan provinsi-provinsi di Indonesia berdasarkan karakteristik faktor penyebab balita stunting dilakukan melalui analisis cluster hierarki metode ward. 


\section{Metode Penelitian}

\section{Analisis Cluster Hierarki}

Analisis cluster merupakan salah satu metode analisis statistik yang bertujuan mengelompokkan obyek berdasarkan kesamaan karakteristik di antara obyek-obyek tersebut (Ghozali, 2016). Konsep yang relatif sama juga ditunjukkan pada literatur lain yang menyatakan bahwa clustering atau lebih dikenal dengan analisis cluster merupakan proses pengelompokan satu set benda fisik ataupun abstrak ke dalam satu kelas objek yang sama (Prasetyo, 2012). Dengan demikian dapat disimpulkan bahwa analisis cluster merupakan salah satu metode pengolahan data yang efektif untuk pengelompokan data dalam kelompokkelompok yang memiliki kesamaan karakteristik.

Analisis cluster memiliki dua metode pengelompokkan, yaitu metode hierarki dan non hierarki (Handoyo, 2014). Analisis cluster secara hierarki memiliki beberapa cara pengelompokkan, antara lain linkage method (single linkage, average linkage, complete linkage), ward's method, dan centroid method. Sedangkan analisis cluster secara non hierarki memiliki tiga cara pengelompokkan, yaitu sequential thereshold, parallel thereshold, dan optimizing partitioning (Johnson, 2014).

Analisis cluster dengan pendekatan non hierarki pada dasarnya memiliki dua kekurangan. Pertama, jumlah atau banyaknya kelompok ditentukan terlebih dahulu. Kedua, pemilihan pusat kelompok tidak menentu sehingga hasil pengelompokkan sangat tergantung pada bagaimana pusat kelompok dipilih (Uyanto, 2009). Dengan demikian dapat disimpulkan bahwa hasil pengelompokkan menggunakan analisis cluster secara non hierarki tergantung pada observasi data. Berdasarkan kekurangan-kekurangan ini, maka analisis cluster secara non hierarki akan sangat tepat dan bermanfaat jika jumlah observasi data relatif besar (Gudono, 2011). Oleh karena itu, penelitian ini akan menggunakan analisis cluster secara hierarki, sebab jumlah observasi data yang relatif kecil yakni 34 provinsi. Adapun metode pengelompokkan yang dipilih untuk mengelompokkan provinsi di Indonesia berdasarkan kesamaan faktor penyebab balita stunting adalah Ward's Method, atau Metode Ward.

Menurut Uyanto (2009), konsep dasar dari analisis klaster adalah ukuran kedekatan antar obyek yang dapat dilakukan dengan cara menghitung jarak diantara dua obyek. Tujuannya adalah untuk memperoleh matriks ketaksamaan yang memuat semua jarak diantara dua obyek. Pengukuran jarak yang paling umum dalam analisis klaster hierarki devisif adalah pengukuran jarak Euclid. Rumus persamaan untuk menghitung jarak Euclid adalah:

$$
d(x, y)=\sqrt{\left(x_{1}-y_{1}\right)^{2}+\left(x_{2}-y_{2}\right)^{2}+\cdots+\left(x_{p}-y_{p}\right)^{2}}
$$

dengan keterangan $\mathrm{d}(\mathrm{x}, \mathrm{y})$ adalah jarak diantara obyek $\mathrm{x}$ dan $\mathrm{y} ; \mathrm{x}_{\mathrm{i}}$ dan $\mathrm{y}_{\mathrm{i}}$ adalah nilai-nilai untuk obyek $\mathrm{x}$ dan y pada variabel ke-i dan $\mathrm{p}$ adalah jumlah variabel.

\section{HASIL DAN PEMBAHASAN}

\section{Prevalensi Balita Stunting di Indonesia}

Tinggi badan balita stunting pada dasarnya tidak memenuhi tinggi badan normal sesuai umurnya. Kondisi stunting ini sebagai akibat dari tidak terpenuhinya gizi anak yang berlangsung lama. Pada 2017, terdapat 29,6 persen balita dengan tinggi badan di bawah normal. Secara detail, prevalensi ini terdiri dari 9,8 persen balita sangat pendek dan 19,8 persen balita pendek. Secara keseluruhan, angka prevalensi ini mengalami peningkatan jika dibandingkan dengan kondisi 2016. Pada 2016, prevalensi balita stunting di Indonesia sebesar 27,56 persen yang terdiri dari 8,57 persen balita sangat pendek dan 18,97 persen balita pendek.

Pada 2017, prevalensi balita stunting berdasarkan provinsi di Indonesia sangat bervariasi. Dua provinsi dengan prevalensi tertinggi di Indonesia adalah Provinsi Nusa Tenggara Timur dan Sulawesi Barat, yakni masing-masing sebesar 40,2 persen dan 40,1 persen. Kedua provinsi ini, menurut klasifikasi WHO, termasuk prevalensi kategori sangat tinggi, karena lebih dari 40 persen. Sedangkan dua provinsi yang memiliki prevalensi terendah adalah Provinsi Bali dan DI Yogyakarta dengan 
prevalensi masing-masing sebesar 19,1 persen dan 19,8 persen. Kedua provinsi ini termasuk kategori prevalensi rendah, karena kurang dari 20 persen. Adapun jumlah provinsi yang termasuk dalam kategori sedang (20 - 29 persen) dan tinggi (30 - 39 persen), masing-masing adalah 13 dan 17 provinsi. Dengan demikian, mayoritas provinsi di Indonesia memiliki prevalensi balita stunting kategori tinggi dan sangat tinggi.

\section{Pengelompokkan Provinsi Menurut Karakteristik Faktor Stunting}

Tahap awal pengelompokkan adalah melakukan uji asumsi dalam analisis cluster. Terdapat dua asumsi yang harus dipenuhi dalam analisis cluster. Pertama, sampel yang diambil telah representatif atau mewakili populasi. Kedua, tidak terjadi mulitikolinieritas antar variabel. Untuk asumsi pertama, dapat dilihat dari nilai Kaiser Meyer Olkin (KMO). Apabila nilai KMO yang diperoleh lebih besar 0,5 maka asumsi pertama terpenuhi. Sementara itu untuk menguji asumsi kedua adalah melalui nilai VIF setiap variabel. Apabila nilai VIF kurang dari 10, maka dapat dikatakan tidak terjadi multikolinieritas (Santoso, 2018).

TABEL 1. KMO and Bartlett's Test

\begin{tabular}{llc}
\hline $\begin{array}{l}\text { Kaiser-Meyer-Olkin Measure of Sampling } \\
\text { Adequacy. }\end{array}$ & .732 \\
\hline Bartlett's Test of Sphericity & Approx. Chi-Square & 84.731 \\
\cline { 2 - 3 } & $\mathrm{df}$ & 21 \\
\cline { 2 - 3 } & Sig. & .000 \\
\hline Sumber: data diolah. &
\end{tabular}

Berdasarkan TABEL 1 di atas, nilai KMO yang diperoleh sebesar 0,732. Nilai ini lebih besar dari 0,5. Hal ini berarti asumsi pertama dalam analisis cluster telah terpenuhi, yakni sampel yang diambil telah representatif atau mewakili populasi.

TABEL 2. Hasil Uji Multikolinieritas

\begin{tabular}{|c|c|c|c|c|c|c|c|c|}
\hline \multicolumn{9}{|c|}{ Coefficients $^{\mathrm{a}}$} \\
\hline & Model & $\mathrm{B}$ & Std. Error & Beta & $\mathrm{t}$ & Sig & Tolerance & VIF \\
\hline \multirow[t]{8}{*}{1} & (Constant) & 30,579 & 0,760 & & 40,246 & 0,000 & & \\
\hline & $\mathrm{x} 1$ & $-3,940$ & 1,387 & $-0,702$ & $-2,841$ & 0,009 & 0,309 & 3,233 \\
\hline & $\mathrm{x} 2$ & 1,857 & 1,247 & 0,331 & 1,488 & 0,149 & 0,382 & 2,616 \\
\hline & $\mathrm{x} 3$ & $-0,539$ & 0,914 & $-0,096$ & $-0,590$ & 0,560 & 0,711 & 1,406 \\
\hline & $\mathrm{x} 4$ & 0,658 & 1,026 & 0,117 & 0,641 & 0,527 & 0,565 & 1,769 \\
\hline & $\mathrm{x} 5$ & $-0,732$ & 1,163 & $-0,130$ & $-0,629$ & 0,535 & 0,440 & 2,275 \\
\hline & $x 6$ & $-1,738$ & 0,955 & $-0,310$ & $-1,819$ & 0,080 & 0,652 & 1,535 \\
\hline & $\mathrm{x} 7$ & 0,648 & 1,020 & 0,115 & 0,636 & 0,531 & 0,572 & 1,748 \\
\hline
\end{tabular}

Sumber: data diolah.

TABEL 2 merupakan hasil Uji Multikolinieritas menggunakan nilai VIF. Berdasarkan TABEL 2 tersebut, seluruh variabel memiliki nilai VIF yang lebih kecil dari 10. Hal ini berarti asumsi kedua dalam analisis cluster, yakni tidak terjadi multikolinieritas, telah terpenuhi. Berdasarkan hasil uji kedua asumsi tersebut, maka seluruh asumsi dalam analisis cluster telah terpenuhi. Langkah berikutnya adalah melakukan standarisasi variabel ke bentuk Zscore, sebab satuan variabel yang digunakan bervariasi. Hasil standarisasi disajikan pada TABEL 3.

Hasil standarisasi di atas kemudian digunakan dalam pengelompokkan provinsi-provinsi di Indonesia berdasarkan karakteristik faktor penyebab balita stunting. Pengelompokkan dilakukan dengan analisis cluster hierarki metode ward. Hasil pengelompokkan menggunakan metode ini disajikan pada TABEL 4. 
TABEL 3. Standarisasi Variabel

\begin{tabular}{|c|c|c|c|c|c|c|c|}
\hline Provinsi & ZX1 & ZX2 & ZX3 & ZX4 & ZX5 & ZX6 & ZX7 \\
\hline 1 Aceh & -.17371 & -.58523 & -.98437 & 129.120 & -114.224 & -.63311 & .00119 \\
\hline 2 Sumatera Utara & .53079 & -.04606 & -216.183 & -.78647 & .23300 & -.60674 & .15315 \\
\hline 3 Sumatera Barat & -.95072 & -.17413 & .26705 & -.10297 & -.26110 & -.05021 & .39370 \\
\hline 4 Riau & .31402 & .47556 & -.44846 & -.30228 & -.87048 & .20928 & -.01915 \\
\hline 5 Jambi & -.11366 & -.49433 & .86827 & .86640 & .62004 & -.37712 & -.04906 \\
\hline 6 Sumatera Selatan & .04452 & -.67096 & 142.531 & 158.211 & .94121 & -.54865 & 109.499 \\
\hline 7 Bengkulu & -168.745 & -275.637 & -.73850 & -210.514 & .24124 & -.29331 & -.06584 \\
\hline 8 Lampung & -.94193 & -172.761 & -.09887 & .58556 & .82592 & -.84067 & .29085 \\
\hline 9 Kep. Bangka Belitung & 130.414 & -.24540 & -.52049 & .74259 & .73533 & 113.713 & .40553 \\
\hline 10 Kep. Riau & 150.699 & 138.760 & -.37739 & .92982 & .48005 & 192.517 & .52726 \\
\hline 11 Dki Jakarta & 185.851 & 190.199 & 128.317 & 125.798 & 126.237 & 359.712 & .31346 \\
\hline 12 Jawa Barat & -.09902 & -.00164 & .47 & .98 & 12 & .14 & .93994 \\
\hline 13 Jawa Tengah & .44584 & .57575 & .83081 & .91573 & 110.591 & -.53946 & -.27704 \\
\hline 14 Di Yogyakarta & 173.182 & .68937 & 270.938 & .76071 & .63651 & .28360 & 112.878 \\
\hline 15 Jawa Timur & .22541 & .51894 & .16141 & .94995 & 105.650 & -.49471 & .20753 \\
\hline 16 Banten & .43412 & -.45508 & .68963 & .49395 & .04360 & .71574 & 108.915 \\
\hline 17 Bali & 181.311 & 210.030 & -.16033 & -129.783 & 126.237 & 102.539 & 100.802 \\
\hline 18 Nusa Tenggara Barat & .25617 & -.00371 & .76262 & .36712 & .52122 & -.94983 & .58650 \\
\hline 19 Nusa Tenggara Timur & -149.704 & -.54908 & .95086 & .59965 & -106.812 & -148.928 & -.67546 \\
\hline 20 Kalimantan Barat & -117.921 & -.18033 & .60608 & .11849 & -.10463 & -.53207 & -125.105 \\
\hline 21 Kalimantan Tengah & -148.606 & -.68335 & -.37450 & -.25698 & .09301 & .26355 & .38843 \\
\hline 22 Kalimantan Selatan & -.56112 & -102.214 & .34004 & .92177 & -.19522 & .35178 & 139.340 \\
\hline 23 Kalimantan Timur & .51834 & 126.366 & .11531 & -.15028 & .66945 & 145.768 & -.95215 \\
\hline 24 Kalimantan Utara & .06137 & 137.005 & .43608 & .06010 & -.85401 & .91594 & -111.538 \\
\hline 25 Sulawesi Utara & .45243 & .28654 & -.94211 & -142.164 & -.26933 & .15429 & 143.230 \\
\hline 26 Sulawesi Tengah & -.33922 & -.35283 & -.89601 & -.07479 & .40594 & -.57376 & .40828 \\
\hline 27 Sulawesi Selatan & .80395 & .60157 & .85386 & .16580 & .74357 & -.53681 & .76837 \\
\hline 28 Sulawesi Tenggara & .27594 & .96205 & -119.566 & -.56602 & -.54109 & -.82356 & .13573 \\
\hline 29 Gorontalo & -.51278 & .46316 & -197.263 & -.10096 & -.26933 & -.65093 & .22885 \\
\hline 30 Sulawesi Barat & -.45932 & -101.801 & .79432 & -.39590 & -.16228 & -133.026 & -.46547 \\
\hline 31 Maluku & -.18031 & -.22475 & -.58099 & -135.219 & -214.690 & -.62977 & -185.128 \\
\hline 32 Maluku Utara & .03134 & -.49433 & -.71353 & -.66165 & -124.106 & -.54112 & -268.808 \\
\hline 33 Papua Barat & -.03311 & .26898 & -113.707 & -184.845 & -.89519 & .21296 & -194.108 \\
\hline 34 Papua & -239.415 & -118.017 & -.27078 & -216.755 & -311.863 & .05051 & -154.436 \\
\hline
\end{tabular}

TABEL 4 menggambarkan hasil pengelompokkan provinsi di Indonesia berdasarkan karakteristik faktor penyebab stunting menjadi dua, tiga, dan empat kelompok. Pada dasarnya tidak ada standard atau prosedur untuk menentukan jumlah kelompok. Para peneliti telah mengembangkan beberapa kriteria dan petunjuk sebagai pendekatan terhadap permasalahan ini dengan memperhatikan substansi dan aspek konseptual (Santoso, 2018). Pada penelitian ini, dipilih jumlah cluster sebanyak empat cluster. Pemilihan ini bertujuan untuk melihat pengelompokkan provinsi berdasarkan faktor penyebab balita stunting dari tingkat rendah, sedang, tinggi, dan sangat tinggi.

Hasil pengelompokkan provinsi di Indonesia ke dalam empat kelompok adalah sebagai berikut.

a. Kelompok 1 terdiri dari 16 provinsi yaitu Aceh, Sumatera Utara, Sumatera Barat, Riau, Bengkulu, Lampung, Banten, Nusa Tenggara Timur, Kalimantan Barat, Kalimantan Tengah, Kalimantan Selatan, Sulawesi Utara, Sulawesi Tengah, Sulawesi Tenggara, Gorontalo, dan Sulawesi Barat.

b. Kelompok 2 terdiri dari 8 provinsi yaitu Jambi, Sumatera Selatan, Jawa Barat, Jawa Tengah, DI Yogyakarta, Jawa Timur, Nusa Tenggara Barat, dan Sulawesi Selatan.

c. Kelompok 3 terdiri dari 6 provinsi yaitu Kepulauan Bangka Belitung, Kepulauan Riau, DKI Jakarta, Bali, Kalimantan Timur, dan Kalimantan Utara.

d. Kelompok 4 terdiri dari 4 provinsi yaitu Maluku, Maluku Utara, Papua Barat, dan Papua. 
TABEL 4. Hasil Pengelompokkan Provinsi di Indonesia Berdasarkan Karakteristik Faktor Penyebab Stunting

\begin{tabular}{|c|c|c|c|}
\hline Provinsi & 4 Clusters & 3 Clusters & 2 Clusters \\
\hline 1 Aceh & 1 & 1 & 1 \\
\hline 2 Sumatera Utara & 1 & 1 & 1 \\
\hline 3 Sumatera Barat & 1 & 1 & 1 \\
\hline 4 Riau & 1 & 1 & 1 \\
\hline 5 Jambi & 2 & 2 & 2 \\
\hline 6 Sumatera Selatan & 2 & 2 & 2 \\
\hline 7 Bengkulu & 1 & 1 & 1 \\
\hline 8 Lampung & 1 & 1 & 1 \\
\hline 9 Kep. Bangka Belitung & 3 & 2 & 2 \\
\hline 10 Kep. Riau & 3 & 2 & 2 \\
\hline 11 Dki Jakarta & 3 & 2 & 2 \\
\hline 12 Jawa Barat & 2 & 2 & 2 \\
\hline 13 Jawa Tengah & 2 & 2 & 2 \\
\hline 14 Di Yogyakarta & 2 & 2 & 2 \\
\hline 15 Jawa Timur & 2 & 2 & 2 \\
\hline 16 Banten & 1 & 1 & 1 \\
\hline 17 Bali & 3 & 2 & 2 \\
\hline 18 Nusa Tenggara Barat & 2 & 2 & 2 \\
\hline 19 Nusa Tenggara Timur & 1 & 1 & 1 \\
\hline 20 Kalimantan Barat & 1 & 1 & 1 \\
\hline 21 Kalimantan Tengah & 1 & 1 & 1 \\
\hline 22 Kalimantan Selatan & 1 & 1 & 1 \\
\hline 23 Kalimantan Timur & 3 & 2 & 2 \\
\hline 24 Kalimantan Utara & 3 & 2 & 2 \\
\hline 25 Sulawesi Utara & 1 & 1 & 1 \\
\hline 26 Sulawesi Tengah & 1 & 1 & 1 \\
\hline 27 Sulawesi Selatan & 2 & 2 & 2 \\
\hline 28 Sulawesi Tenggara & 1 & 1 & 1 \\
\hline 29 Gorontalo & 1 & 1 & 1 \\
\hline 30 Sulawesi Barat & 1 & 1 & 1 \\
\hline 31 Maluku & 4 & 3 & 1 \\
\hline 32 Maluku Utara & 4 & 3 & 1 \\
\hline 33 Papua Barat & 4 & 3 & 1 \\
\hline 34 Papua & 4 & 3 & 1 \\
\hline
\end{tabular}

Sumber: data diolah.

\section{Karakteristik Kelompok}

Setelah kelompok terbentuk maka tahap selanjutnya adalah memberi ciri spesifik untuk menggambarkan isi kelompok tersebut. Identifikasi karakteristik dalam penelitian ini dilakukan melalui analisis deskriptif. Berdasarkan analisis deskriptif dapat disusun posisi relatif rata-rata atau proporsi kelompok terhadap rata-rata atau proporsi nasional. Hasil analisis deskriptif ini dapat memberikan gambaran awal karakteristik masing-masing kelompok.

TABEL 5. Rata-rata Variabel Pada Setiap Cluster

\begin{tabular}{|c|c|c|c|c|c|}
\hline Variabel & 1 & 2 & 3 & 4 & Nasional \\
\hline (1) & (2) & (3) & (4) & $(5)$ & $(6)$ \\
\hline $\mathrm{X} 1$ & 59,11 & 71,38 & 81,83 & 56,96 & 67,89 \\
\hline $\mathrm{X} 2$ & 66,06 & 71,99 & 83,07 & 66,57 & 72,04 \\
\hline $\mathrm{X} 3$ & 29,23 & 43,77 & 34,59 & 26,21 & 35,73 \\
\hline $\mathrm{X} 4$ & 55,24 & 54,73 & 49,10 & 31,57 & 51,32 \\
\hline$\times 5$ & 91,56 & 94,33 & 91,07 & 90,87 & 90,80 \\
\hline X6 & 967.683 & 969.070 & 1.500 .516 & 1.008 .102 & 1.036 .497 \\
\hline $\mathrm{X7}$ & 2.161 & 2.119 & 2.183 & 2.158 & 2.153 \\
\hline
\end{tabular}

Sumber: data diolah. 
Berdasarkan TABEL 5, dapat diketahui karakteristik masing-masing kelompok yaitu kelompok I yang memiliki karakteristik tingkat inisiasi menyusui dini, imunisasi lengkap, dan rata-rata konsumsi kalori yang relatif tinggi. Namun tingkat ASI eksklusif dan rata-rata pengeluaran rumah tangga perkapita relatif rendah. Selain itu kondisi sanitasi dan sumber air minum belum layak. Berdasarkan karakteristik ini, maka kelompok ini merupakan kelompok dengan faktor stunting tinggi. Berdasarkan kesamaan karakteristik di atas, maka untuk provinsi- provinsi yang terdapat pada kelompok satu, pemerintah dapat menerapkan kebijakan berupa edukasi dini tentang pentingnya ASI eksklusif untuk balita. Edukasi ini dapat diintegrasikan dalam bimbingan pranikah yang dilakukan oleh Kementerian Agama kepada pasangan yang akan menikah. Selain itu pemerintah juga dapat fokus pada program perbaikan sanitasi dan sumber air minum masyarakat. Program ini dapat dilakukan melalui optimalisasi dana desa untuk perbaikan sanitasi dan peningkatan aksesbilitas terhadap air bersih.

Kelompok II memiliki karakteristik kondisi sanitasi yang sudah layak serta tingkat ASI eksklusif, inisiasi menyusui dini, dan imunisasi lengkap yang relatif tinggi. Namun kondisi sumber air minum belum layak serta rata-rata pengeluaran rumah tangga dan konsumsi kalori perkapita masih rendah. Berdasarkan karakteristik ini, maka kelompok ini merupakan kelompok dengan faktor stunting sedang. Berdasarkan kesamaan karakteristik di atas, maka untuk provinsi- provinsi yang terdapat pada kelompok dua, pemerintah dapat fokus pada upaya-upaya perbaikan kesejahteraan masyarakat. Perbaikan kesejahteraan ini diharapkan mampu meningkatkan konsumsi kalori masyarakat. Selain itu dengan tingkat kesejahteraan yang semakin meningkat, maka masyarakat dapat memiliki akses terhadap sumber air minum yang lebih layak.

Kelompok III memiliki karakteristik tingkat ASI eksklusif dan inisiasi menyusui dini yang masih rendah. Namun dari aspek kondisi sanitasi dan sumber air minum relatif baik. Selain itu tingkat imunisasi lengkap, rata-rata pengeluaran rumah tangga dan konsumsi kalori perkapita yang relatif tinggi. Berdasarkan karakteristik ini, maka kelompok ini merupakan kelompok dengan faktor stunting rendah. Berdasarkan kesamaan karakteristik di atas, maka untuk provinsi-provinsi yang terdapat pada kelompok tiga, pemerintah lebih fokus pada edukasi tentang pentingnya ASI eksklusif dan inisiasi menyusui dini bagi balita. Apabila dilihat provinsi-provinsi yang berada dalam kelompok ini, beberapa merupakan provinsi yang didominasi wilayah perkotaan seperti DKI Jakarta dan Bali. Hal ini diduga ada kaitannya dengan tingkat mobilitas dan intensitas pekerjaan penduduk perkotaan, terutama perempuan, yang relatif tinggi. Tingginya tingkat mobilitas dan intensitas pekerjaan perempuan ini secara tidak langsung menyebabkan perempuan cenderung tidak mampu memberikan ASI eksklusif kepada anaknya. Oleh karena itu, program edukasi tentang ASI eksklusif dan inisiasi dini ini terutama ditujukan kepada penduduk di perkotaan. Selain itu, pemerintah dapat menetapkan kebijakan untuk mewajibkan kantorkantor perusahaan, termasuk instansi pemerintah, menyediakan ruang laktasi. Hal ini bertujuan agar perempuan bekerja tetap dapat memberikan ASI eksklusif kepada anaknya.

Kelompok IV memiliki karakteristik tingkat imunisasi lengkap dan rata- rata konsumsi kalori yang relatif tinggi. Namun kondisi sanitasi dan sumber air minum belum layak. Selain itu tingkat ASI eksklusif, inisiasi menyusui dini, dan rata-rata pengeluaran rumah tangga masih relatif rendah. Berdasarkan karakteristik ini, maka kelompok ini merupakan kelompok dengan faktor stunting sangat tinggi. Berdasarkan kesamaan karakteristik di atas, maka provinsi-provinsi yang terdapat pada kelompok empat ini memerlukan perhatian dan upaya lebih dari pemerintah. Kelompok ini merupakan provinsi-provinsi yang terletak di Indonesia bagian timur, yaitu provinsi-provinsi di Pulau Papua dan Maluku. Hampir dari semua aspek, kondisi di provinsi-provinsi tersebut relatif jauh tertinggal dibandingkan dengan provinsi lain. Oleh karena itu, pemerintah harus membuka akses seluas-luasnya bagi setiap penduduk di provinsi-provinsi tersebut dalam memperoleh pelayanan dasar, terutama kesehatan dan pendidikan. Pemerintah harus memastikan dan menjamin bahwa setiap penduduk dapat tumbuh sehat dan terdidik.

Kunci utama dari seluruh kebijakan untuk provinsi-provinsi di kelompok empat ini adalah perbaikan tingkat pendidikan. Pendidikan akan mampu mengubah paradigma penduduk terkait semua aspek, termasuk pentingnya sanitasi, sumber air minum, ASI eksklusif, dan inisiasi menyusui dini. Selain itu, pendidikan sebagai salah satu bentuk investasi, tentu akan dapat meningkatkan pendapatan dan kesejehteraan penduduk. Pada akhirnya, penduduk yang terdidik ini akan dapat tumbuh menjadi penduduk yang sehat dan mandiri secara ekonomi. 


\section{KESIMPULAN DAN SARAN}

\section{Kesimpulan}

Pada 2017, prevalensi balita stunting di Indonesia sebesar 29,6 persen. Berdasarkan klasifikasi WHO, hanya terdapat 2 provinsi yang tergolong prevalensi rendah. Sementara itu, terdapat 17 provinsi yang tergolong prevalensi tinggi dan 2 provinsi dengan prevalensi sangat tinggi. Adapun sisanya, sebanyak 13 provinsi memiliki prevalensi balita stunting kategori sedang. Pengelompokkan provinsi di Indonesia berdasarkan faktor penyebab stunting menggunakan analisis cluster metode ward menghasilkan 4 kelompok dimana kelompok pertama beranggotakan 16 provinsi dengan karakteristik faktor penyebab stunting tinggi, kelompok kedua beranggotakan 8 provinsi dengan karakteristik faktor penyebab stunting sedang, kelompok ketiga beranggotakan 6 provinsi dengan karakteristik faktor penyebab stunting rendah, sedangkan kelompok keempat beranggotakan 4 provinsi dengan karakteristik faktor penyebab stunting sangat tinggi.

\section{Saran}

Pengelompokkan provinsi di Indonesia berdasarkan faktor penyebab stunting menggunakan analisis cluster metode ward menghasilkan 4 kelompok dimana kelompok pertama beranggotakan 16 provinsi dengan karakteristik faktor penyebab stunting tinggi. Untuk kelompok pertama, pemerintah dapat merumuskan kebijakan berupa edukasi tentang pentingnya ASI eksklusif serta program perbaikan sanitasi dan sumber air minum. Kelompok kedua beranggotakan 8 provinsi dengan karakteristik faktor penyebab stunting sedang. Bagi kelompok ini, pemerintah harus fokus pada upaya-upaya meningkatkan kesejahteraan masyarakat. Kelompok ketiga beranggotakan 6 provinsi dengan faktor penyebab stunting rendah. Untuk kelompok ini pemerintah dapat mewajibkan kantor-kantor perusahaan dan instansi pemerintah untuk menyediakan fasilitas ruang laktasi. Sedangkan kelompok keempat beranggotakan 4 provinsi dengan karakteristik faktor penyebab stunting sangat tinggi. Bagi kelompok ini, pemerintah harus membuka akses seluas-luasnya bagi setiap penduduk dalam memperoleh pelayanan dasar, terutama akses kesehatan dan pendidikan.

\section{UCAPAN TERIMA KASIH}

Terima kasih kepada Bapak/Ibu pimpinan BPS Provinsi Sumatera Utara dan BPS Kabupaten Padang Lawas Utara atas kesempatan untuk menimbah ilmu pada level magister sehingga penulis dapat lebih mengasah kemampuan melalui tulisan ini.

\section{REFERENSI}

Alrahmad, Hendra, A., \& Miko, A 2016, 'Kajian Stunting Pada Anak Balita Berdasarkan Pola Asuh Dan Pendapatan Keluarga Di Kota Banda Aceh' Jurnal Kesmas Indonesia, pp. 63-79.

Bappenas 2011, 'Rencana Aksi Nasional Pangan dan Gizi 2011-2015' Jakarta: Bappenas.

Bertalina, \& Amelia, P 2018, 'Hubungan Asupan Gizi, Pemberian ASI Eksklusif, dan Pengetahuan Ibu dengan Status Gizi Tb/U Balita 6-59 Bulan’ Jurnal Kesehatan, pp. 117-125.

BPS. 2014, 'Kajian Indikator Sustainable Development Goals SDGs' Jakarta: Badan Pusat Statistik.

Ghozali, I. 2016, 'Aplikasi Analisis Multivariete dengan Program IBM SPSS 23 Edisi 8' Semarang: Universitas Diponegoro.

Gudono. 2011, 'Analisis Data Multivariat Edisi Pertama' Yogyakarta: BPFE.

Handoyo, R 2014, 'Perbandingan Metode Clustering Menggunakan Metode Single Linkage Dan K Means Pada Pengelompokan Dokumen' Jurnal ISSN, pp. 75-76.

Johnson, R 2014, 'Applied Multivariate Statistical Analisis’ America: Thomson Learning Academic. 
Kemenkes. 2016, 'Data dan Informasi Profil Kesehatan Indonesia 2015' Jakarta: Kementerian Kesehatan Republik Indonesia.

Kemenkes. 2016, 'Situasi Balita Pendek di Indonesia' Jakarta: Pusat Data dan Informasi - Kementerian Kesehatan Republik Indonesia.

Kemenkes. 2017, 'Data dan Informasi Profil Kesehatan Indonesia 2016' Jakarta: Kementerian Kesehatan Republik Indonesia.

Kemenkes. 2018, 'Data dan Informasi Profil Kesehatan Indonesia 2017' Jakarta: Kementerian Kesehatan Republik Indonesia.

Ni'mah, K., \& Nadhiroh, S. R 2015, 'Faktor yang Berhubungan dengan Kejadian Stunting pada Balita' Media Gizi Indonesia, pp. 13-19.

Notoatmodjo, S 2013, 'Promosi Kesehatan dan Perilaku Kesehatan' Jakarta: Rineka Cipta.

Permadi, \& Rizal, M 2016, 'Risiko Inisiasi Menyusu Dini dan Praktek ASI Eksklusif Terhadap Kejadian Stunting Pada Anak 6-24 Bulan’ Jurnal Penelitian Gizi dan Makanan, 9-14.

Prasetyo 2012, 'Data Mining Konsep dan Aplikasi Menggunakan Matlab' Yogyakarta: Penerbit Andi.

Santoso, S. 2018, 'Mahir Statistik Multivariat dengan SPSS' Jakarta: Elex Media Computindo.

Supariarsa 2012, 'Penilaian Status Gizi' Jakarta: Penerbit Buku Kedokteran EGC.

TNP2K 2017, 'Ringkasan 100 Kabupaten/Kota Prioritas untuk Intervensi Anak Kerdil Stunting' Jakarta: TNP2K-Sekretariat Wakil Presiden Republik Indonesia.

TNP2K 2018 November 19, 'Gerakan Nasional Pencegahan Stunting dan Kerjasama Kemitraan Multi Sektor’ Jakarta: TNP2K - Sekretariat Wakil Presiden Republik Indonesia.

Unicef 2012, 'Ringkasan Kajian Gizi Ibu dan Anak’ Jakarta: Unicef Indonesia.

Utomo, B. S 2018, 'Bersama Cegah Stunting' Jakarta: Kementerian Kesehatan Republik Indonesia.

Uyanto, S 2009, 'Pedoman Analisis Data dengan SPSS, Edisi 3' Yogyakarta: Graha Ilmu.

Wellina, W. F., Kartasurya, M., \& Rahfilludin, M 2016, 'Faktor Resiko Stunting pada Anak Umur 12 24 Bulan' Jurnal Gizi Indonesia, 55-61.

WHO 2014, 'WHA global nutrition targets 2025: Stunting policy brief' Geneva: World Health Organization.

Wijaya, T 2010, 'Analisis Multivariat Teknik Olah Data Untuk Skripsi Tesis dan Disertasi Menggunakan SPSS’ Yogyakarta: Universitas Atma Jaya. 